\title{
GDF9 wt Allele
}

National Cancer Institute

\section{Source}

National Cancer Institute. GDF9 wt Allele. NCI Thesaurus. Code C51539.

Human GDF9 wild-type allele is located in the vicinity of 5q31.1 and is approximately $3 \mathrm{~kb}$ in length. This allele, which encodes growth differentiation factor 9 protein, is involved in ovarian folliculogenesis. 